\title{
Studies on the Microflora of Ripe Pawpaw (Carica papaya) Fruits in Ghana
}

\author{
Isaac G. Dukuh ${ }^{1}$, Yaw Opoku-Asiamah ${ }^{2}$ \\ ${ }^{1}$ Department of Agricultural Engineering, Bolgatanga Polytechnic, Bolgatanga, Ghana \\ Email: isaacgdukub@yahoo.co.uk \\ ${ }^{2}$ Department of Crop Science, University of Cape Coast, Cape Coast, Ghana
}

\begin{abstract}
The aim of the study is to identify fungi associated with fruit rot of pawpaw both in the field and in storage. Three experiments were conducted. In the first experiment, fungi growing on ripe pawpaw fruits randomly collected from plants on the UCC campus were identified in the laboratory. The position on the fruit the fungi appeared was recorded. The second experiment involved the storage of fruits in insect proof containers in the laboratory to indentify fungi growing on the fruits and the position on the fruit the fungi appeared. In the third experiment, fruits were washed with $10 \%$ solution of Milton 2 before they were stored in insect proof containers. Fungi which grew on them and the position on the fruit the fungi appeared were identified. The survey revealed that Collectotricum gloesporiodes which cause anthracnose was the most frequently occurring fungi in the field in the study area. The most serious fungi diseases of pawpaw in storage were found to be anthracnose, stem end rot and black rot which were caused by Collectotricum gloesporiodes, Phomopsis caricae-papayae and Phoma caricae-papayae.It was demonstrated that surface sterilization with 10\% Milton 2 solution increased the shelf life of the stored fruits for 2-3 days.
\end{abstract}

Keywords: Carica papaya; Microflora; Milton 2; Surface sterilization; Frequency of occurrence.

\section{Introduction}

In Ghana, not much is known about the cultivation of pawpaw. Recently a small number of pawpaw farms have been cultivated around Nsawam in the Eastern Region of the country. There is prospect for commercial production of the crop as it has export potential and most people in Ghana take pawpaw as dessert.

Pawpaw is widely cultivated and it also grows wild in the tropical world. There is a growing trade between the growing areas and the consuming centres such as Western Europe and United Sates of America. Unfortunately, this trade is severely limited by postharvest deterioration. The post-harvest deterioration is attributed to factors such as climate, physiological changes, chemical injury and pathological decay of the fruit (Snowdon, 1989).

Anthracnose is a well-known disease of most papaya growing countries. Chau and Alvarex (1983) stated that air currents carry the spores to developing fruits and if conditions remain moist for some hours the fungus develops a swelling called appresorium, from which an infection thread penetrates the skin. According to Tsai (1969), there is a high incidence of pawpaw anthracnose under hot-wet conditions. In Hawaii, the main cause of stem-end rotting is Phoma caricae-papaya but Phomopsis carocae-papayae and Phytophthora palmivora can also cause this type of rot (Hunter and Buddenhagen, 1972). Gupta and Pathak (1986) reported that Aspergillus niger, Rbizopus flavus, Rhizopus nigrican, Convularia lunata, Rhizopus oryzae, Fusarium equiseti and Fusarium moniliforme were responsible for post harvest losses of pawpaw in Southern Western Nigeria.

In the Philippines, Botryodiplodia theobromae is associated with stem-end rot (Lantican and Quimio, 1976). Phomopsis carocae-papayae and Botryodiplodia theobromae cause stem end rot of papayas in the USA (Stevens, 1939). Hunter and Buddenhagen (1972) pointed out that Phoma caricae-papaya is the conidia state of the fungus causing Black Rot of papayas. According to Broderick et al (1976) and Hine et al (1964) Phoma caricae-papayae appears as a dry firm dark rot which extends into the fruit from the stem end.

Bolken et al. (1976) reported that Black Rot disease is important in Brazil. The occurrence of the disease has been reported in South Africa by Broderick et al. (1976). 
Pathological decay is an important aspect of postharvest deterioration. Infection by fungi and bacteria may occur during the growing season, at harvest time, during handling, storage, transport and marketing or even after purchase by the consumer (Dennis, 1983). Studies on the microflora of pawpaw have been done in places like Hawaii, India, and the Philippines. According to Baiyewu et al (2007), in Nigeria, the most common fungi found in rotten pawpaw fruits are: Rhizopus nigricans, Curvularia lunata, Aspergillus flavus, Aspergillus niger, Fusarium moniliforme, Colletotrichum capsici and Trichoderma viride. In Ghana not much has been done on causes of postharvest losses in pawpaw.

The objective of this study was therefore to identify fungi associated with fruit rot of pawpaw both in the field and in storage.

\section{Methodology}

The study was carried out at the Department of Crop Science of the School of Agriculture, University of Cape Coast (UCC).

\subsection{Researchdesign}

The pawpaw fruits were randomly collected from pawpaw trees growing in the Northern section of the University Campus. The vegetation of the area is coastal savannah with two distinct rainy seasons. The major rainy season is between March and July ending while the minor season is between September and end of November. Mean annual rainfall of the area is $940 \mathrm{~mm}$, minimum mean annual temperature is about $25{ }^{\circ} \mathrm{C}$ and relative humidity is $90 \%-100 \%$ but reduces considerably in the dry periods.

\subsection{Test}

Three studies were undertaken which include:

\subsubsection{Identification of fungi on the ripe parpare in the field}

A total of 14 fruits were collected from the field over a period of 5 weeks starting on the $9^{\text {th }}$ of May. Fungi on the fruit were identified at the laboratory by looking at the growth characteristics and microscopic examination of spores of fungi. Also noted was the position on the fruit the fungi was observed.

\subsubsection{Identification of fungi which grow on ripe parparw in storage}

Six ripe pawpaw fruits were harvested from the field at a time and kept in disinfected glass containers covered with muslin. The fruits were stored at room temperature for seven days and they were examined for any fungal growth every day for six days. Identification was done by looking at the growth characteristics and also by microscopic examination of spores.

\subsubsection{Identification of fungi growing on ripe pawpaw fruit with sterilized surface}

Six pawpaw fruits were harvested from the field at a time. Three of them were surface sterilized with $10 \%$ Milton 2 solution. The fruits were bathed in the solution for 30 minutes, removed and air dried. The surface sterilized fruits were kept in disinfected glass containers covered with muslin for 7 days. The fruits were examined each day for six days for fungi growth. The fungi observed on the fruit were identified using a microscope.

\subsection{Data collection and analysis}

Data were collected on the following:

i. Fungal species

ii. Day of first appearance on the fruit after harvest

iii. Frequency of occurrence (Number of fruits on which fungi were observed)

iv. Position on fruit first observed

Analysis of results: Frequency of occurrence was converted to percentage to represent population of fruits on which fungi were observed.

\section{Results}

A number of fungi causing pathological decay and skin blemish to the fruits were observed on the pawpaw fruits used for the study both on the field and in storage. It was observed that fruits harvested halfripe and turning yellow stored well longer than fully ripe fruits. Fully ripe fruits could not be stored for more than two days, while half- ripped and turningyellowish fruits could be stored for 3-4 days. 


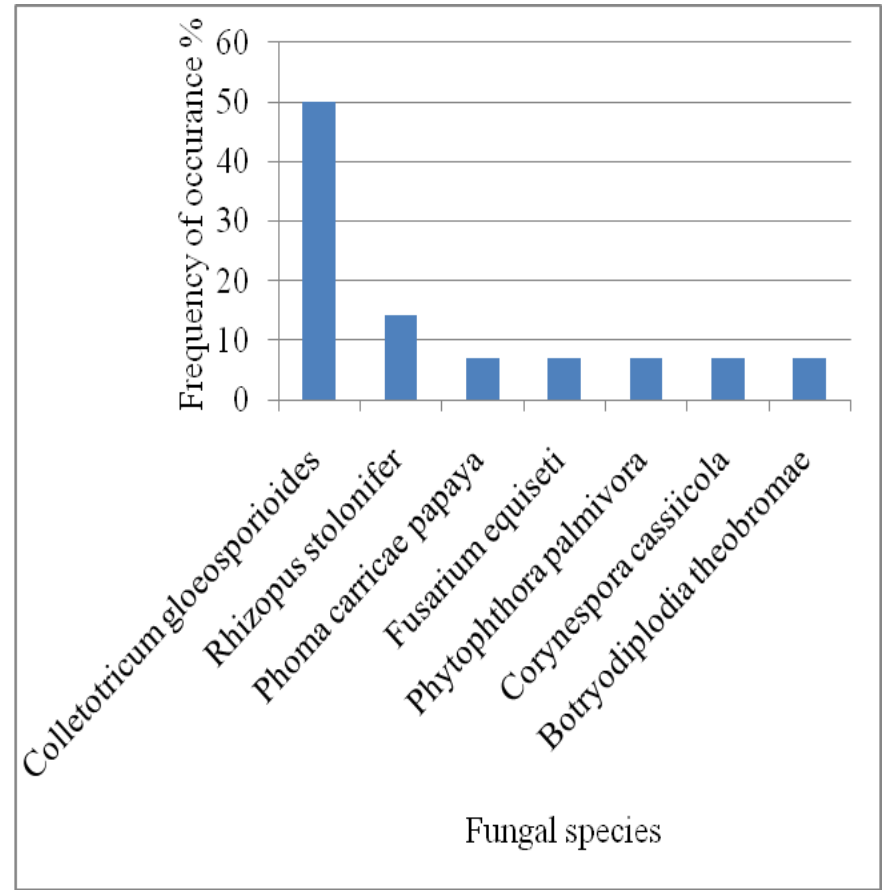

Fig. 1: Fungi observed on ripe pawpaw in the field.

Figure 1, is the given frequency of occurrence of pathogenic fungi. All the pathogenic fungi were observed on one side of the fruit. Figure 1 shows Colletotrichum gloeosporioides was most prevalent fungus in the field.

Table 1

Fungi observed on ripe pawpaw in storage under room conditions

\begin{tabular}{lccl}
\hline Fungalspecies & $\begin{array}{l}\text { Day of first } \\
\text { appearance }\end{array}$ & $\begin{array}{l}\text { Frequency of } \\
\text { occurrence } \\
\%\end{array}$ & $\begin{array}{l}\text { Position on } \\
\text { fruit first } \\
\text { observed }\end{array}$ \\
\hline $\begin{array}{l}\text { Phomopsis caricae } \\
\text { papavae }\end{array}$ & 2 & 58 & Stem end \\
$\begin{array}{l}\text { Colletotricum } \\
\text { gloeosporioides }\end{array}$ & 2 & 58 & Side of fruit \\
$\begin{array}{l}\text { Phoma carricae } \\
\text { papava }\end{array}$ & 2 & 58 & $\begin{array}{l}\text { Near stem } \\
\text { end } \\
\text { Rhizopus stolonifer } \\
\text { Asperisporium } \\
\text { caricae }\end{array}$ \\
$\begin{array}{l}\text { Phytophthora } \\
\text { palmivora }\end{array}$ & 2 & 25 & $\begin{array}{l}\text { Side of fruit } \\
\text { Cercospora } \\
\text { pappaea }\end{array}$ \\
$\begin{array}{l}\text { Thricothecium } \\
\text { roseum }\end{array}$ & 1 & 25 & Side of fruit \\
$\begin{array}{l}\text { Botryodiplodia } \\
\text { theobromae }\end{array}$ & 2 & 16.7 & Side of fruit \\
\hline
\end{tabular}

In table 1 , are the given fungal species observed on the pawpaw fruit in storage and the frequency of occurrence. Table 1 also shows the day of first appearance and position fungal species were first observed on the fruit.
It is clear from table 1 that the most prevalent fungi on fruit under stored conditions were Phomopsis carocae-papayae, Colletotrichum gloeosporioides and Phoma caricae-papayae. These Rhizopus stolonifer and Asperisporium caricae were the next prevalent fungi under room coditions. Phytophthora palmivora was the third most predominant fungi. The fungi with the least frequency of occurrence on pawpaw fruit in storage were Cercospora pappadea, Tricothecium roseum and Botryodiplodia theobromae. It can also be seen from table 1 that except Cercospora pappaea which was seen on day 5 after harvest, all the fungi first appeared on the fruit on day 1 and day 2 after harvest.

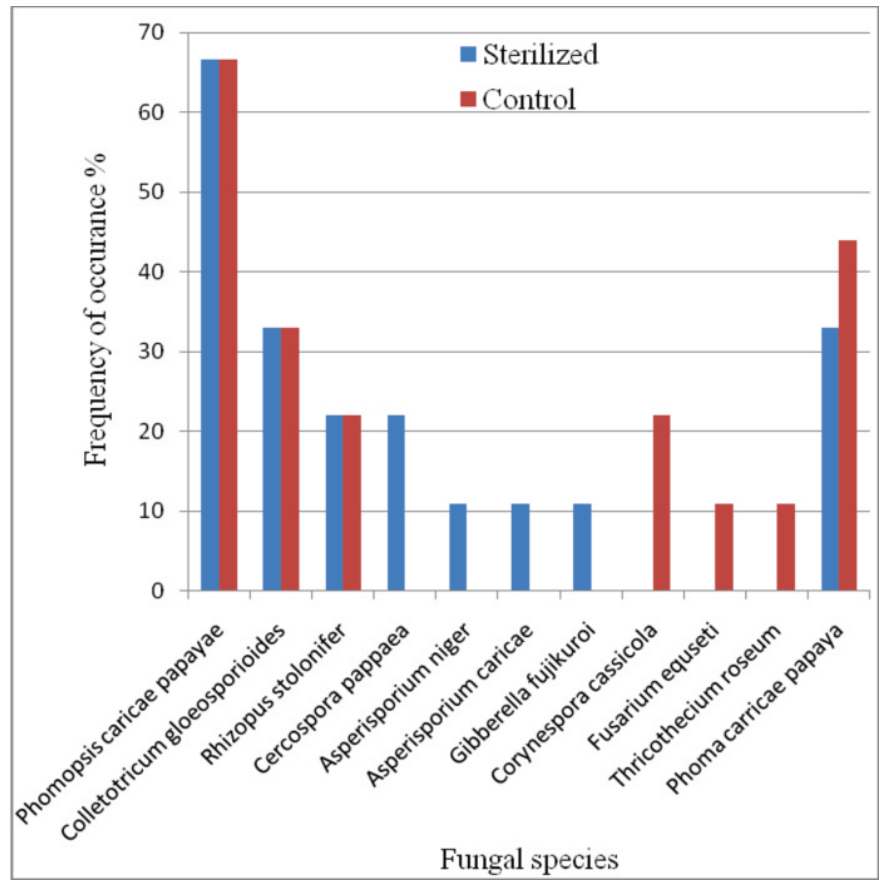

Fig. 2: Fungi observed on ripe pawpaw in the field.

The figure shows that Phoma caricae-papaya was the most predominant fungus whether the pawpaw fruits were surface sterilized or not. The prevalence of Colletotricum gloeosporioides, Phoma carricae papaya and Rbizopus stolonifer followed in that order. Cercospora pappaea, Asperisporium niger, Asperisporium caricae and Gibberella fujikuroi were observed on surface sterilized fruits, but not on unsterilized fruits. However, Corynespora cassicola, Fusarium equseti and Thricothecium roseum were observed on unsterilized fruits. 


\section{Discussion}

The many fungal species found on the ripe fruit both in the field and in storage suggest that the pawpaw fruit is vulnerable to a number of pathogenic fungi. The frequency of occurrence of Colletotrichum gloeosporioides both in storage and in the field was high which probably indicates that this fungus might be the main cause of the anthracnose of pawpaw fruit. According to Tsai (1969), there is a high incidence of pawpaw anthracnose under hot-wet conditions. During the study the temperature averaged about $25^{\circ}$ $\mathrm{C}$ and the rainfall was about $940 \mathrm{~mm}$ and studies have shown that the optimal temperature for the infection of Colletotrichum gloeosporioides has been reported to be about $26{ }^{\circ} \mathrm{C}$. Colletotrichum gloeosporioides found on pawpaw fruits stored in insect proof containers suggest that the spores of the fungus is air-borne. The spores could have landed on the fruit surface after they had been sterilized. However, it could be possible that the rate at which Milton 2 was applied (10\%) was not effective enough to eliminate the spores of the fungi. Rhizopus stolonifer and Phoma caricae-papayae were also found in storage on surface sterilized fruits. This is an indication that the spores of these fungi are airborne. It is also possible that the $10 \%$ solution of Milton 2 could not eliminate the spores from the surface through sterilization. It is interesting to note that Phoma caricae-papayae was not a serious problem in field as in storage as is realized in the table 1. It is possible that pawpaw fruit only get infected through stem cut end after the fruit have been harvested. This observation seems to agree with what has been reported by Broderick et al (1976) and Hine et al (1964) that Phoma caricae-papayae appear as a dry firm dark rot which extends into the fruit from the stem end.

There were fungi such as Asperisporium caricae, Gibberella fujikuroi, Aspergillus niger and Tricothecium roseum which were only found in storage. It is likely that these fungi thrive better in storage and thereforepose a threat to pawpaw fruits. The disappearance of most of the observed fungi after the first day of storage suggests that they could be eliminated in storage if the surface of the fruits was sterilized. Except Botryodiplodia theobromae, the observed fungi were located on parts of the pawpaw fruit reported in literature. In the study, Botryodiplodia theobromae was found on the sides of pawpaw fruits whereas in literature it is reported to cause stem-end-rot. Probably this variance was caused by different strain of Botryodiplodia theobromae.

\section{Conclusion}

It was observed in this study that fungi which grow on ripe pawpaw fruit in the field were Colletotrichum gloeosporioides, Phoma caricae-papayae, Phomopsis caricae-papayae, Rhizopus stolonifer, Phytophthora palmivora, Fusarium equiseta, Corynespora cassiicola and Botryodiplodia theobromae.

The most prevalent fungi species on pawpaw fruit in the field of the coastal savanna zone of Ghana are Colletotrichum gloeosporioides which cause anthracnose.

Fungal species encountered in the field were also encountered in the storage in addition to Phomopsis caricae-papayae. Phomopsis caricae-papayae which grows exclusively at the cut stem end and Colletotrichum gloeosporioides were very prevalent in storage. Two possible sources of fungal infection in storage were derived from the study. The spores of the fungi are air-borne and probably ubiquitous. The study also suggests possible systemic growth of the fungi after the pawpaw fruit had been infected through stem cut end after harvesting.

Milton 2 was observed to extend the shelf life of pawpaw. However, Milton 2 could not control the growth of Colletotrichum gloeosporioides, Phoma caricae-papayae, Phomopsis caricae-papayae and Rhizopus stolonifer on the pawpaw fruit.

\section{Recommendation}

Higher concentrations of Milton 2 solution should be further evaluated to determine the concentration that can control Colletotrichum gloeosporioides, Phoma caricae-papayae, Phomopsis caricae-papayae and Rhizopusstolonifer.

\section{References}

Baiyewu, R A.,Amusa, N. A. Ayoola, O. A., and Babalola, O. O., (2007). Survey of Post Harvest Diseases and Aflotoxin Contamination of Marketed Pawpaw Fruits, African Journal of Agricultural Research, Vol. 2, No. 4, pp. 178-181.

Bolkan, H. A., Cupertino, F. P., Dianese, J. C. and Takatsu, A., (1976). Fungi Associated with Pre and Post-Harvest Fruit Rots of Papaya and their Control in Central Brazil, Plant Disease Reporter, Vol. 60, pp. 605-609. 
Broderick, H. T., Thomas, A. C. Visser, F. and Beyer, S. M., (1976). Studies on the Use of Gamma Irradiation and Hot Water Treatments for Shelf Life Extension, Plant Disease Reporter, Vol.60, pp. 749-753.

Chau, K. F. and Alvarex, A. M., (1983). A histological Study of Anthracnose in Carica papaya, Phytopathology, Vol.73, pp. 1113-1116.

Dennis, C., (1983). Post-Harvest Pathology of Fruits and Vegetables, Academic Press, London, pp. 264

Gupta, A. K. and Pathak, V. N., (1986). Survey of Fruit Market for Papaya Fruit Rot by Fungi Pathogens, Indian Journal Mycol, Vol. 16, pp. 152-154.

Hine, R. B., Trujillo, E. E. and Stanghellini, M. E., (1964). Stem-End Rot and Other Fruit Rots of Papaya, Hawaii Farm Science, Vol. 13, pp. 5-6.
Hunter, J. E. and Buddenhagen, I. W., (1972). Incidence, Epidemiology and Control of Fruit Diseases of Papaya in Hawai, Tropical Agriculture, Vol. 49, pp. 61-71.

Lantican, M. T. and Quimio, T. H., (1976). Pathogenicity and Cultural Characteristics of Botryodiplodia spp. Causing Fruit Rots, Philippine Pathology, Vol. 12, pp. 66-74.

Snowdon, A. L., (1989). A Colour Atlas of Post-Harvest Diseases and Disorders of Fruits and Vegetables; General Introduction of Fruits, Wolfe Scientific, London, Vol. 1, pp. 302.

Stevens, H. E., (1939). Papaya Diseases, Proceedings of Florida State Horticultural Society, Vol. 52, pp 57-63.

Tsai, W. H., (1969). Studies on Ecology and Physiology of Papaya Anthracnose and its Control, Journal of Taiwanese Agricultural Research, Vol. 18, pp. 51-57. 